\title{
Electrochemical treatment of actual sugar industry wastewater using aluminum electrode
}

\author{
O. P. Sahu $\cdot$ V. Gupta $\cdot$ P. K. Chaudhari $\cdot$ \\ V. C. Srivastava
}

Received: 5 May 2014/Revised: 7 January 2015 / Accepted: 28 January 2015/Published online: 19 February 2015

(C) Islamic Azad University (IAU) 2015

\begin{abstract}
In the present study, electrochemical (EC) treatment of sugar industry wastewater (SIWW) was investigated using aluminum electrode. Effect of various parameters such as $\mathrm{pH}$, current density (CD), electrode gap and electrolysis time was evaluated for chemical oxygen demand (COD) and color reduction. Energy requirement and electrode loss were found to increase with an increase in $\mathrm{pH}$. Kinetics studies showed that the COD reduction rate was second order with respect to organic materials (COD) and 0.591 order with respect to CD. Filtration of treated slurry was found to be best near the neutral $\mathrm{pH}$, while settling was best at $\mathrm{pH} 10$. Operating cost of the treatment has been calculated. Results demonstrate that EC can be applied to reduce pollution load of SIWW.
\end{abstract}

Keywords COD removal $\cdot$ Color removal $\cdot$ Current density $\cdot$ Filtration $\cdot$ Settling

\section{Introduction}

Sugar industry is one of the largest agro-based industries in the world. Among the various sugar-producing countries, India is the second largest producer and consumer of sugar

Electronic supplementary material The online version of this article (doi:10.1007/s13762-015-0774-5) contains supplementary material, which is available to authorized users.

O. P. Sahu $(\varangle) \cdot$ V. Gupta $\cdot$ P. K. Chaudhari

Department of Chemical Engineering, National Institute of

Technology, Raipur 492010, Chhattisgarh, India

e-mail: ops0121@gmail.com

V. C. Srivastava

Department of Chemical Engineering, Indian Institute of

Technology Roorkee, Roorkee 247667, Uttarakhand, India per annum. In sugar industry, around $1.5-2 \mathrm{~m}^{3}$ of water is consumed and about $1 \mathrm{~m}^{3}$ of effluent is generated for every ton of cane processed (Asaithambi and Matheswaran 2011). Effluents are generated from various sections of plants such as from floor washing, condensate, leakage and spillage of cane juice in various parts. Wastewaters coming out from these sections have different characteristics; therefore, equalization is done so as to have common characteristics of the discharged effluent. In a typical sugar industry, the grit and suspended solids are removed by passing it through bar screening. After that, it is taken to equalization tank where compressed air is passed for uniform distribution of components present in it. Wastewater of equalization tank contains BOD $1,700-6,000 \mathrm{mg} / \mathrm{dm}^{3}$, chemical oxygen demand (COD) $2,300-8,000 \mathrm{mg} / \mathrm{dm}^{3}$ and suspended solids about $5,000 \mathrm{mg} / \mathrm{dm}^{3}$ (EHS 2007). Apart from these, it contains pathogens and contaminated materials.

Release of effluent without proper treatment leads to serious environmental and health problems; therefore, proper treatment is necessary before its discharge into the water bodies. Physicochemical and biological (aerobic and or anaerobic) processes are most commonly applied in sugar industry. Anaerobic treatment has advantage of producing methane-rich gas, but limitation of this process is its ability to decompose part of organics; therefore, it is further treated by biological oxidation process. Another option to treat sugar industry wastewater (SIWW) is coagulation with alum in the presence of lime followed by biological oxidation. Both processes are collectively not able to produce treated effluent up to the discharge standards for release into surface water $\left(C O D<100 \mathrm{mg} / \mathrm{dm}^{3}\right)$ and serves $\left(\mathrm{COD}<300 \mathrm{mg} / \mathrm{dm}^{3}\right)$ prescribed by World Health Organization (WHO). Treated effluent is dark black in color, which resists oxygen diffusion and sunlight penetration causing death of aquatic life. 
Different methods and technologies such as coagulation (Tan et al. 2000; Chaudhari et al. 2007), aerobic and anaerobic treatments (LaPara et al. 2000), advanced oxidation process (Esplugas et al. 2002; Asaithambi et al. 2014), adsorption (Faust and Aly 1987) and electrolysis (Szpyrkowicz et al. 1995; Sridhar et al. 2014) have been reported to treat industrial wastewaters. These treatment processes require high capital and operating cost. Among various technologies, electrochemical (EC) treatment is one of the best economical alternative processes (Chen 2004; Ponselvan et al. 2009) when conventional treatment methods fail to reduce pollution among industrial effluents (Brillas et al. 1998). EC process is a recently developed technique which is being employed in the treatment of various wastewaters (Kim et al. 2002; Aoudj et al. 2010; Serge et al. 2010; Kamaraj et al. 2013; Maleki et al. 2014; Ndjomgoue-Yossa et al. 2014). It is a simple, efficient, safe, flexible and cost-effective treatment process (Bayramoglu et al. 2004, 2007; Guven et al. 2009). Less sludge generation, less chemicals requirement, little space requirement, shorter residence time and colorless treated effluent production are some advantages of this process (Ahlawat et al. 2008). Kushwaha (2013) has shown various treatment technologies to treat SIWW in his review article. Some works have been reported on treatment of simulated SIWW by EC process (Guven et al. 2009; Asaithambi and Matheswaran 2011); however, no work has been reported to treat original cane-based SIWW.

The present paper aimed to use aluminum electrodes for the removal of COD and color from the SIWW. Effects of $\mathrm{pH}, \mathrm{CD}$, electrode gap (EG) and treatment time $\left(t_{\mathrm{R}}\right)$ have been studied on the removal of COD and color. Kinetics of the treatment process has been studied, and settling and filterability characteristics of the EC-treated SIWW and operating cost has also been reported.

\section{Materials and methods}

\section{Materials}

Wastewater used for experiments was from Bhoramdev Sugar Industry Ltd., Kawardha, Chhattisgarh, India. The composition of effluent before and after treatment is presented in Table 1. Analytical grade chemicals made by Merck Limited, Mumbai, India, were used for analysis. The aluminum sheet was used as electrode which was purchased from local market.

\section{Experimental method}

The complete setup of experimental program is shown in Fig. 1 and dimension is given in Table 2. EC reactor (ECR)
Table 1 Characteristics of SIWW before and after treatment at CD $178 \mathrm{~A} / \mathrm{dm}^{2}, \mathrm{EG}=20 \mathrm{~mm}, \mathrm{pH} 7$

\begin{tabular}{llll}
\hline S. no & Characteristics & Before treatment & After treatments \\
\hline 1 & Color & Dark brown & Pale yellow \\
2 & pH & 5.5 & 8.24 \\
3 & COD & 3,682 & 699 \\
5 & Phosphate & 5.9 & 2.1 \\
6 & Protein & 43 & 16 \\
7 & Total solid & 1,987 & 757 \\
8 & Suspended solid & 540 & 247 \\
9 & Dissolved solid & 1,447 & 510 \\
10 & Chloride & 50 & 18 \\
11 & Hardness & 900 & 422 \\
\hline
\end{tabular}

All the values except $\mathrm{pH}$ and color is in $\mathrm{mg} / \mathrm{dm}^{3}$

was made of Perspex glass in which four aluminum anode and cathode electrodes were arranged in parallel mono-polar mode and connected with DC power supply. Current flow through the cell and the voltage across the electrodes were measured with an ammeter and a voltmeter, respectively. A magnetic bar and speed regulator were also placed for mixing the effluent during the treatment. For treatment, $1.4 \mathrm{dm}^{3}$ of SIWW was taken in $1.5 \mathrm{dm}^{3}$ ECR, and after treatment time intervals, $10 \mathrm{ml}$ sample was taken in test tube and sludge contained in it was allowed to settle. Supernatant liquid was analyzed for COD, color and other parameters. Temperature of the suspension in EC reactor was measured using a thermometer. Before each run, the electrodes were washed with $10 \% \mathrm{HCl}$ to remove grease and impurities on the electrode surfaces.

Analytical procedure

COD of the sample was determined by the standard dichromate open reflux method (Clesceri et al. 1989). Chloride concentration was determined by the standard titrimetric Volhard method (Vogal 1958). Sulfate was determined by gravitational method. Phosphate was estimated by using standard methods (Clesceri et al. 1989). The protein content was determined by the Lowry method (Cartier et al. 1997). The color of the sample was measured in terms of the percentage decrease in absorbance at $\lambda=420 \mathrm{~nm}$ (Guimarac et al. 2005; Can et al. 2006). For colorimetric analysis, UV-visible spectrophotometer made by Thermo Electron Corporation, USA, was used.

\section{Results and discussion}

Mechanism of electrochemical treatment

Various types of EC reactions in the reactor depend on electrode materials used in the process. Aluminum and iron 
Fig. 1 Electrochemical experimental setup. (A) anode, (B) cathode,

(C) electrochemical reactor, $(D)$ magnetic bar, $(E)$ magnetic stirrer, $(F)$ DC supply, $(G)$ wire, $(H)$ digital thermometer, $(I)$ water inlet and $(J)$ water outlet

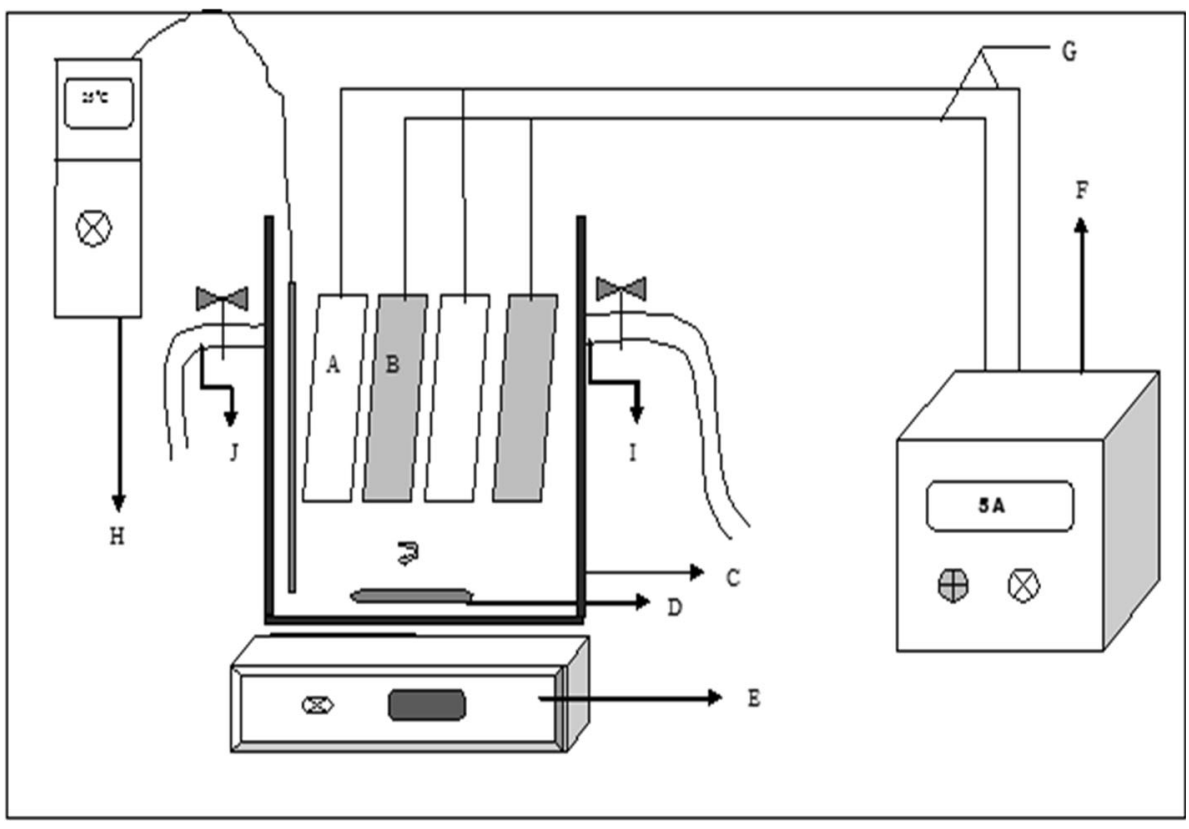

Table 2 Characteristics of EC (Al plate)

\begin{tabular}{|c|c|c|}
\hline \multicolumn{3}{|c|}{ S. no } \\
\hline \multicolumn{3}{|c|}{ Electrode } \\
\hline 1 & Material(anode and cathode) & Aluminum \\
\hline 2 & Shape & Rectangular may be square \\
\hline 3 & Size & $7.5 \mathrm{~cm} \times 7.5 \mathrm{~cm}$ \\
\hline 4 & Thickness & $2 \mathrm{~mm}$ \\
\hline 5 & Plate arrangement & Parallel \\
\hline 6 & Effective electrode surface area & $56.25 \mathrm{~cm}^{2}$ \\
\hline \multicolumn{3}{|c|}{ Reactor characteristics } \\
\hline 1 & Make & Perspex glass \\
\hline 2 & Reactor type & Batch mode \\
\hline 3 & Dimensions $(\mathrm{cm})$ & $10.7 \times 10.7 \times 13.7$ \\
\hline 4 & Volume $\left(\mathrm{dm}^{3}\right)$ & 1.5 \\
\hline 5 & Electrode gap & $15-25 \mathrm{~mm}$ \\
\hline 6 & Stirring mechanism & Magnetic bar \\
\hline \multicolumn{3}{|c|}{ Power supply } \\
\hline 1 & Voltage range & $0-30(\mathrm{~V})$ \\
\hline 2 & Current & $0-5(\mathrm{~A})$ \\
\hline
\end{tabular}

electrodes have been used widely in EC systems. Treatment efficiency of aluminum seems to be superior compared with iron in most cases (Akanksha and Lokesh 2013). But, high cost of aluminum and its adverse effect on health limits its use. In the EC process, coagulants get generated in situ from aluminum electrode material. Charged ionic colloidal species in the wastewater are removed by their interaction with an ion having opposite charge. Steps occurring during EC treatment are as follows: (1) anode dissolution, (2) formation of $\mathrm{OH}^{-}$ions and $\mathrm{H}_{2}$ at the cathode, (3) electrolytic reactions at electrode surfaces,
(4) adsorption of coagulant on colloidal pollutants and (5) removal by sedimentation or flotation (Nordsom and May 1989; Kushwaha et al. 2011). When aluminum electrodes are used, the following EC reactions occur (Singh et al. 2013a, b, c):

At the anode:

$\mathrm{Al}_{(\mathrm{s})} \rightarrow \mathrm{Al}_{(\mathrm{aq})}^{3+}+3 \mathrm{e}^{-}$
$2 \mathrm{H}_{2} \mathrm{O} \rightarrow 4 \mathrm{H}_{(\mathrm{aq})}^{+}+\mathrm{O}_{2}+4 \mathrm{e}^{-}$

At the cathode, depending on $\mathrm{pH}$ :

$$
\begin{aligned}
& 2 \mathrm{H}_{2} \mathrm{O}_{(\mathrm{l})}+2 \mathrm{e}^{-} \rightarrow \mathrm{H}_{2(\mathrm{~g})}+2 \mathrm{OH}_{(\mathrm{aq})}^{-} \\
& 2 \mathrm{H}_{(\mathrm{aq})}+2 \mathrm{e}^{-} \rightarrow \mathrm{H}_{2(\mathrm{~g})}
\end{aligned}
$$

The $\mathrm{Al}_{(\mathrm{aq})}^{3+}$ ions combine with water and hydroxyl ions to form corresponding hydroxides and/or polyhydroxides as follows (Holt et al. 2005). Monomeric species such as $\mathrm{Al}(\mathrm{OH})^{2+}, \mathrm{Al}(\mathrm{OH})_{2}^{+}$and $\mathrm{Al}(\mathrm{OH})_{4}^{-}$are generated as shown in Eqs. 5, 6 and 8. Amorphous and less soluble species such as $\mathrm{Al}(\mathrm{OH})_{3}$ are generated as shown in Eq. 7 .

$\mathrm{Al}^{3+}+\mathrm{H}_{2} \mathrm{O} \rightarrow \mathrm{Al}(\mathrm{OH})^{2+}+\mathrm{H}^{+}$

$\mathrm{l}(\mathrm{OH})^{2+}+\mathrm{H}_{2} \mathrm{O} \rightarrow \mathrm{Al}(\mathrm{OH})_{2}^{+}+\mathrm{H}^{+}$

$\mathrm{Al}(\mathrm{OH})_{2}^{+}+\mathrm{H}_{2} \mathrm{O} \rightarrow \mathrm{Al}(\mathrm{OH})_{3}+\mathrm{H}^{+}$

$\mathrm{Al}(\mathrm{OH})_{3}+\mathrm{H}_{2} \mathrm{O} \rightarrow \mathrm{Al}(\mathrm{OH})_{4}^{-}+\mathrm{H}^{+}$

The concentration of the various $\mathrm{Al}$ forms present in the solution depends on $\mathrm{pH}$ (Vik et al. 1984). The removal of pollutants takes place by the following mechanism. (1) Aluminum cations and hydroxide complexes acting as coagulants are adsorbed on the SIWW and thus neutralizing 
the colloidal charges and resulting in destabilization of the colloids. (2) The amorphous and neutralized masses adsorb the pollutants during its settling and remove it through the phenomena of sweeping. (3) Hydrogen bubbles formed at the cathode absorb the flocculated species and induce their flotation, thus helping in the removal of lighter colloids by floatation. Bubbles formed also reduce cathode surface fouling which occurs due the deposition of colloids. The net rate of pollutant removal is due to combination of all the three mechanisms.

\section{Effect of initial $\mathrm{pH}$}

\section{Effect of $\mathrm{pH}_{i}$ on $\mathrm{COD}$ and color removal}

The $\mathrm{pH}_{\mathrm{i}}$ has been found to influence highly on treatment of various effluents in EC process. Therefore, its effects on $\mathrm{COD}$ and color reduction were examined at $\mathrm{CD}=89 \mathrm{~A} /$ $\mathrm{m}^{2}$ and $\mathrm{EG}=20 \mathrm{~mm}$ for $t_{\mathrm{R}}=120 \mathrm{~min}$. The results are presented in Fig. 2a, b. It may be seen from the Fig. 2a that the $\mathrm{COD}$ reduction increased with increase in $\mathrm{pH}_{\mathrm{i}}$ from 2 to 7 , after that it decreased with increase in $\mathrm{pH}$. At $\mathrm{pH} 2,4,6$, 7, 8 and 10, COD reductions were $32,42,50,60,52$ and
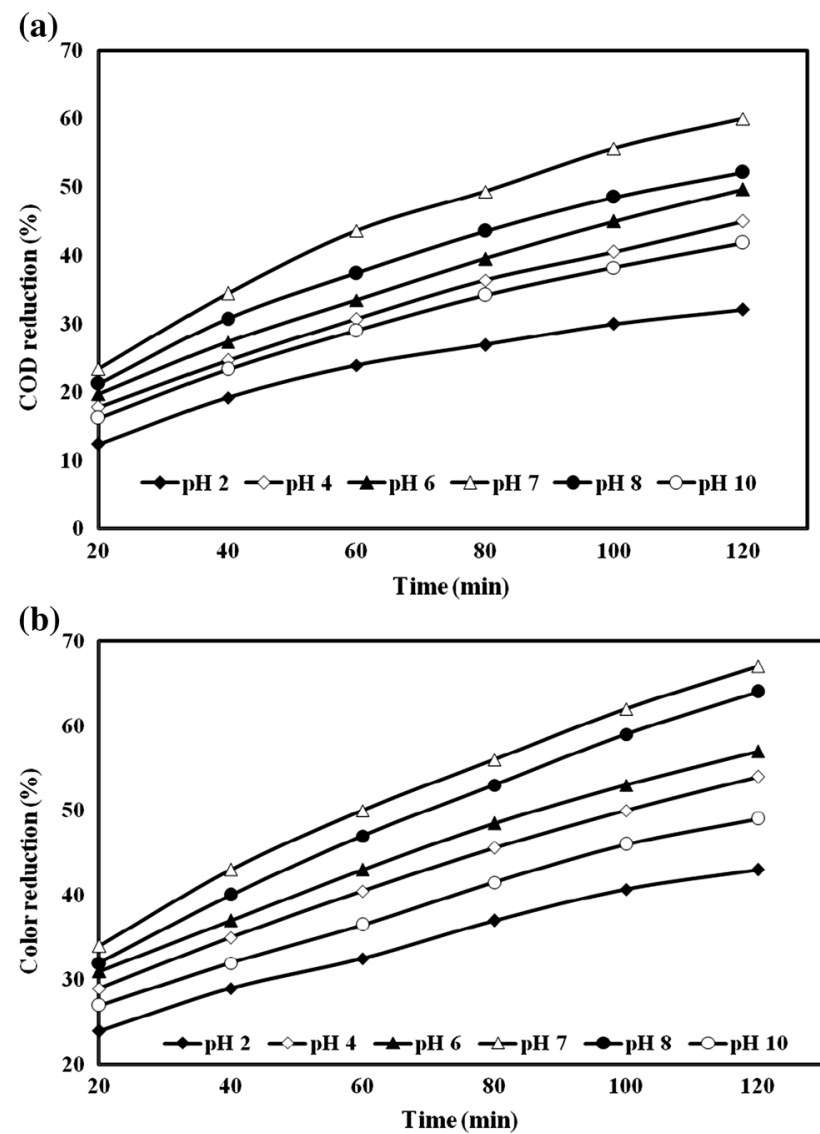

Fig. 2 Effect of $\mathrm{pH}$ on a $\mathrm{COD}$ removal and $\mathbf{b}$ color removal. $\mathrm{CD}$ $89 \mathrm{~A} / \mathrm{m}^{2}$, EG $20 \mathrm{~mm}$
$42 \%$, respectively. The color reductions followed the order of COD reductions and found to increase up to $\mathrm{pH} 7$. The color reductions of $43,49,57$ and $67 \%$ were noted at pH 2, 4, 6 and 7, respectively, which decreased to 64 and $49 \%$ at $\mathrm{pH} 8$ and 10. The COD and color reduction data reflect $\mathrm{pH} 7$ to optimum. Aluminum ions may be found in different forms and phases, depending on the $\mathrm{pH}$ and chemical characteristics of the solution (Aoudj et al. 2010; Serge et al. 2010). It has been reported, at $\mathrm{pH}$ value $<4$, aluminum ions released from electrodes are found in the form $\mathrm{Al}\left(\mathrm{H}_{2} \mathrm{O}\right)_{6}^{3+}$, while at a $\mathrm{pH}$ range of 5-6, aluminum may be in the form $\mathrm{Al}(\mathrm{OH})^{2+}$ and further increase in $\mathrm{pH}$ changes aluminum to $\mathrm{Al}(\mathrm{OH})_{3}$. The changes in $\mathrm{pH}$ also modify the surface charge of colloidal particles present in the effluent and greatly influence its removal. It has also been reported that $\mathrm{pH}$ changes the chemical forms of aluminum and that it affects electrocoagulation efficiency to some extent (Drogui et al. 2008). SIWW contains colloidal suspensions and melanoidins. Both have a net negative charge which react with metal and metal hydroxide cations and form neutral heavy mass which settles down. The other mechanisms involved in the EC treatment have already been discussed.

\section{Effect of pH on energy consumption}

Among the operating cost of electrochemical treatment (ECT), the cost of aluminum electrodes consumption and electrical energy consumption are the most important (Singh et al. 2013b). Energy consumption is defined as energy consumed per unit volume of treated effluent and SEC is defined as the amount of energy consumed per unit volume of effluent treated and per unit mass of COD removed expressed in $\mathrm{kWh} /\left(\mathrm{dm}^{3} \mathrm{~kg}\right.$ COD removed).Energy consumption and specific energy consumption (SEC) were evaluated using Eqs. 9 and 10, respectively.

Energy consumption $\left(\mathrm{Wh} \mathrm{dm}^{-3}\right)=\frac{\text { Vlt }}{\text { Treated volume }\left(\mathrm{dm}^{3}\right)}$

$$
\begin{aligned}
& \operatorname{SEC}\left(\frac{\mathrm{kWh}}{\mathrm{dm}^{3} \mathrm{~kg} \text { COD removal }}\right) \\
& =\frac{\mathrm{Vlt}}{\text { Treated volume }\left(\mathrm{dm}^{3}\right) \mathrm{kg} \text { COD removed }}
\end{aligned}
$$

where $V$ is the voltage across the electrodes, $I$ is the current, and $t$ is the time in hour. To estimate the energy consumption and SEC, experiments were carried out at $\mathrm{CD} 89 \mathrm{~A} / \mathrm{m}^{2}$ and at various $\mathrm{pH}_{\mathrm{i}}$ for a period of $120 \mathrm{~min}$. The results are presented in Fig. $3 \mathrm{a}$ and $3 \mathrm{~b}$. Energy consumption values were found to be $16.20,17.14,20.75$, $22.85,32.10$ and $33.70 \mathrm{kWh} / \mathrm{m}^{3}$ for SIWW treated at $\mathrm{pH}$ $2,4,6,7,8$ and 10 , respectively. During the EC 

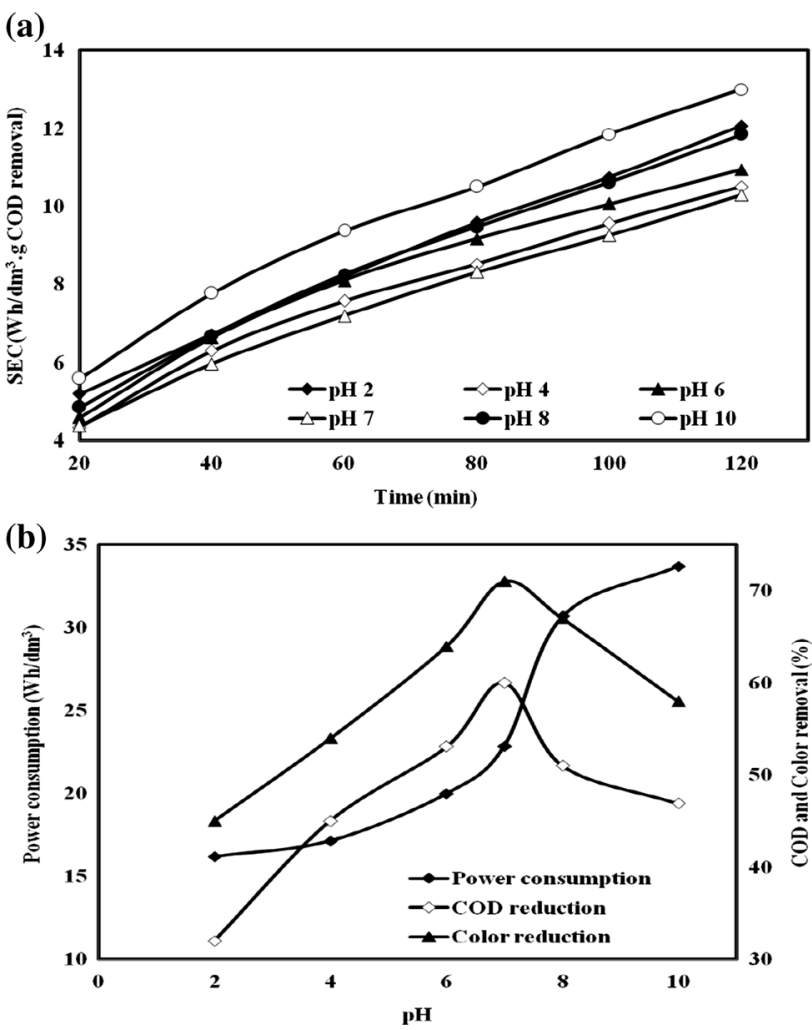

Fig. 3 Effect of $\mathrm{pH}$ on $\mathbf{a}$ specific energy consumption and $\mathbf{b}$ power consumption. CD $89 \mathrm{~A} / \mathrm{m}^{2}$, EG $20 \mathrm{~mm}$

treatment, colloidal flocs adhere to the aluminum electrode surface which further work as an insulator causing an increase in voltage (Maleki et al. 2014). During experiment, voltage was found to increase with increase in $\mathrm{pH}$, which causes high power consumption. The SEC of $12.08,10.52,10.95,10.30,11.85$ and $13.01 \mathrm{kWh} /\left(\mathrm{dm}^{3} \mathrm{~kg}\right.$ COD removal) were obtained at $\mathrm{pH} \mathrm{2,} \mathrm{4,} \mathrm{6,} \mathrm{7,} 8$ and 10, respectively. SEC was not in order of energy consumption. Besides having high energy consumption, SEC was less at $\mathrm{pH} \mathrm{7,} \mathrm{which} \mathrm{is} \mathrm{due} \mathrm{to} \mathrm{relatively} \mathrm{high} \mathrm{COD} \mathrm{re-}$ ductions at different $\mathrm{pH}$.

\section{Effect of $\mathrm{pH}$ on electrode loss}

Electrode losses (EL) were also calculated at different $\mathrm{pH}$. Two anodes and two cathodes were used in experiments. Faraday's law relates current density $(\mathrm{CD})\left(\mathrm{A} / \mathrm{dm}^{2}\right)$ and the amount of substances $(\mathrm{M})$ dissolved $\left(\mathrm{g}\right.$ of $\left.\mathrm{M} / \mathrm{cm}^{3}\right)$ :

$W=\frac{\text { CD.t.M }}{\mathrm{nF}}$

where $W$ is the quantity of electrode material dissolved ( $\mathrm{g}$ of $\left.\mathrm{M} / \mathrm{cm}^{3}\right), \mathrm{CD}$ is the current density $\left(\mathrm{A} / \mathrm{cm}^{2}\right), t$ is time in sec, $\mathrm{M}$ is relative molar mass of the electrode concerned, $n$ is the number of electrons in oxidation/reduction reaction, and $F$ is the Faraday's constant, 96,500 C/mol.
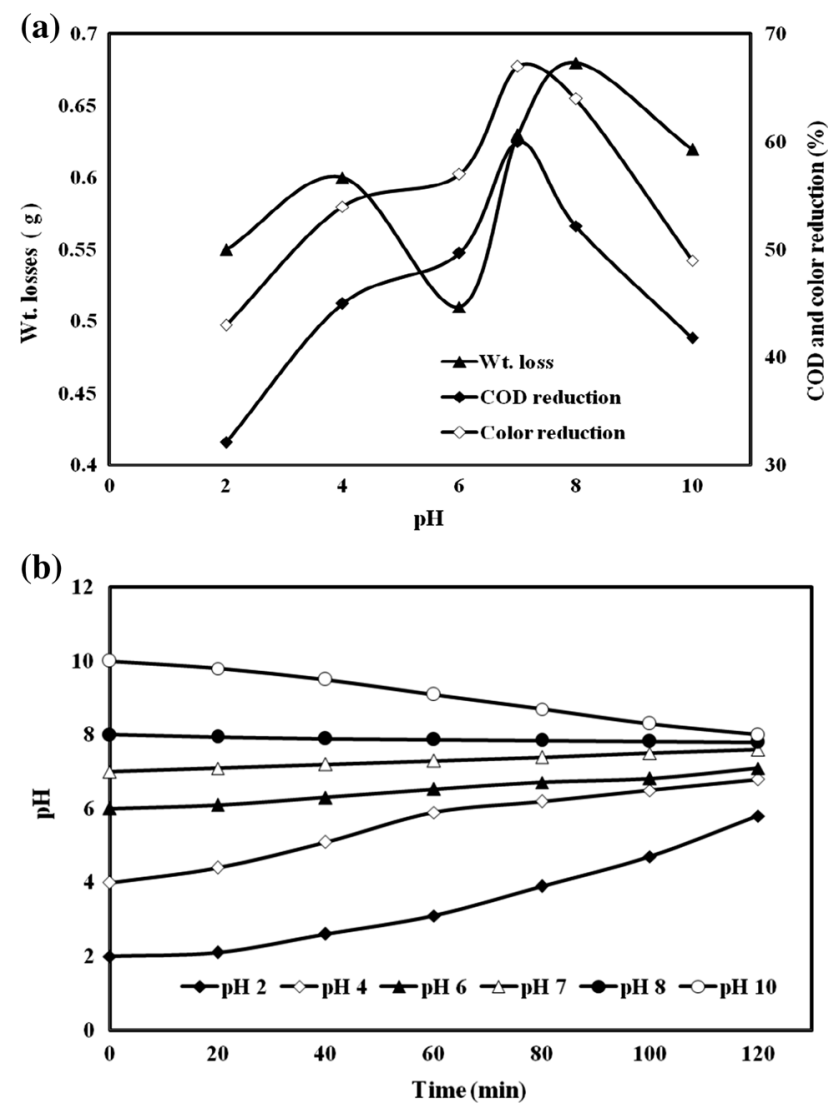

Fig. 4 Effect of $\mathrm{pH}$ on a electrode weight loss and $\mathbf{b}$ change in $\mathrm{pH}$. $\mathrm{pH}_{\mathrm{i}} 7, \mathrm{CD} 89 \mathrm{~A} / \mathrm{m}^{2}$

EL with $\mathrm{pH}$ values is shown in Fig. 4a. EL loss was increased considerably with increase in $\mathrm{pH}$ from $\mathrm{pH}$ 6-8. In the $\mathrm{pH}$ range of $2-6$, EL was the highest at $\mathrm{pH} 4$. The values of EL were estimated to be $0.55,0.60,0.51,0.63$, 0.68 and $0.62 \mathrm{~g} / \mathrm{dm}^{3}$ for SIWW for $2 \mathrm{~h}$ at $\mathrm{pH} 2,4,6,7,8$ and 10, respectively. High EL at basic pH may be due to the presence of more $\mathrm{OH}^{-}$ions which leads to the formation of $\mathrm{Al}(\mathrm{OH})_{3}$ and at acidic $\mathrm{pH}, \mathrm{H}^{+}$attacks anode. Experimental data show that at $\mathrm{pH} 7$, maximum $60 \% \mathrm{COD}$ reduction and $70 \%$ color reduction were obtained with cost of $0.51 \mathrm{~g} / \mathrm{dm}^{3} \mathrm{EL}$ and the lowest SEC $=10.30 \mathrm{kWh} /$ $\left(\mathrm{dm}^{3} \mathrm{~kg}\right.$ COD removal), which shows EC operation at $\mathrm{pH} 7$ is the best. The results obtained are at CD $89 \mathrm{~A} / \mathrm{m}^{2}$. As per Faraday's law represented in Eq. 11, amount of aluminum ions increases with $\mathrm{CD}$. High $\mathrm{CD}$ increases the operation cost as there is increase in energy consumption and metal dissolution. In the process, $79 \%$ COD reduction achieved when $\mathrm{CD}$ increased to $178 \mathrm{~A} / \mathrm{m}^{2}$.

\section{Effect of process time on $\mathrm{pH}$}

$\mathrm{pH}$ has been found to have considerable effect on the efficiency of the EC process, and its value varied with time. Change in $\mathrm{pH}$ depends on the type of electrode material 
and initial $\mathrm{pH}$ of solution. To study the effect of reaction time on $\mathrm{pH}$ change, experiments were performed at $\mathrm{CD}=89 \mathrm{~A} / \mathrm{m}^{2}$ and $\mathrm{EG}=20 \mathrm{~mm}$. $\mathrm{pH}$ of solution was noted at 20-min intervals. Results are presented in Fig. 4b. It was noted that when sample was acidic in nature, the $\mathrm{pH}$ increased. For initial $\mathrm{pH}\left(\mathrm{pH}_{\mathrm{i}}\right)$ of 2, 4, 6 and 7, final $\mathrm{pH}$ was $5.8,6.8,7.1$ and 7.6, respectively. For alkaline $\mathrm{pH}_{\mathrm{i}}$ of 8 and 10 , final $\mathrm{pH}$ decreased to 7.8 and 8.0, respectively. For all the experiments, the rate of change in $\mathrm{pH}$ was found to be fast in the first $40 \mathrm{~min}$ of reaction and became slow later on. This is due to formation of negative- and positivecharged species which varied with $\mathrm{pH}$ of solution. When $\mathrm{pH}_{\mathrm{i}}$ is significantly alkaline $\left(\mathrm{pH}_{\mathrm{i}}>9\right)$, it decreases probably due to the formation of aluminate ion $\left[\mathrm{Al}(\mathrm{OH})_{4}^{-}\right]$, which is an alkalinity consumer (Bayramoglu et al. 2004); however, most of the aluminum ions are in the form $\mathrm{Al}(\mathrm{OH})_{3}$ at basic $\mathrm{pH}$.

\section{Effect of electrode gaps}

The space between two electrodes also affects the electrolysis reaction. It is one of the controlling parameters which can affect the size of the reactor, the EC and overall cost of treatment as well. Effect of EG on treatment of SIWW was carried out at fixed operational condition $\left(\mathrm{pH}_{\mathrm{i}}=7, \mathrm{CD}=89 \mathrm{~A} / \mathrm{m}^{2}\right.$, and $\left.t_{\mathrm{R}}=120 \mathrm{~min}\right)$ and altering gap $(10,15,20$ and $25 \mathrm{~mm})$ between electrodes. The results are presented in Fig. 5. The results show moderate increase in COD removal efficiency (from 38 to $60 \%$ ) with increase in EG from 10 to $20 \mathrm{~mm}$. Further increase in EG to value $25 \mathrm{~mm}$ reduced the COD reduction to $55 \%$. Color reductions followed the same order. At EG of 10, 15, 20 and $25 \mathrm{~mm}, 44.6,54,61$ and $67 \%$ color reductions were obtained, respectively. Decreasing the EG could decrease the flotation process by limiting the generated bubbles in a narrow space which results in higher removal efficiencies. But, there should be proper space for circulation of effluent in ECR. Both the effects contribute to net removal of COD. As EG increases, the resistance also increases, thus, power consumption also increases. Therefore, increase in IR drop by increase in EG between anode and cathode is not recommended in EC process (Vik et al. 1984). The relation between EG and resistance is expressed by the equation:

$R=\frac{\mathrm{EG}}{\mathrm{KA}}$

where $K$ is the cell-specific conductance and $A$ is electrode surface area. Increase in value of EG after certain limit decreases the aluminum oxidation rate and thus decreases COD and color removal efficiency. Based on the results, $20 \mathrm{~mm}$ of spacing was selected as the optimal value of distance between electrodes for the experiments.
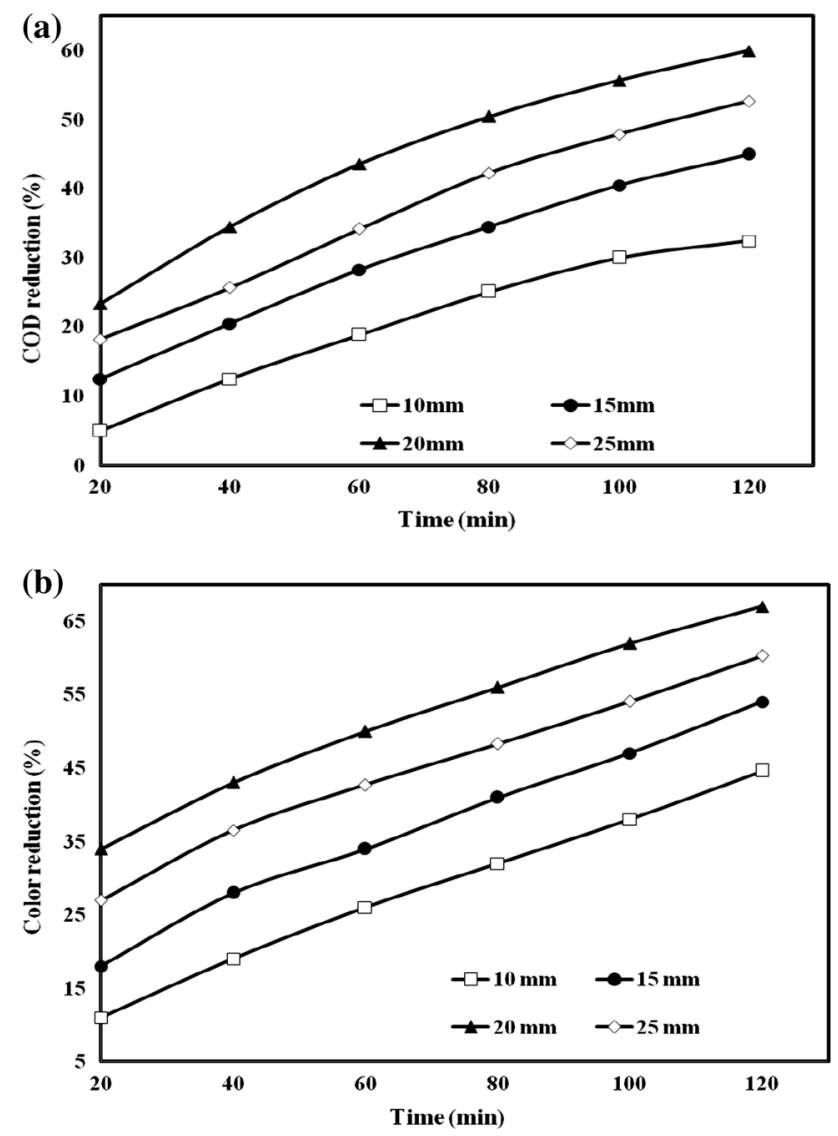

Fig. 5 Effect of electrode gap on a COD removal and b color removal. $\mathrm{pH}_{\mathrm{i}} 7, \mathrm{CD} 89 \mathrm{~A} / \mathrm{m}^{2}$

Effect of current density

\section{Effect of current density on COD and color reduction}

Current density is one of the important parameters which significantly influence the ECT (Mahesh et al. 2006; Asaithambi and Matheswaran 2011). To examine the effect of $\mathrm{CD}$, experiments were performed in the $\mathrm{CD}$ range of 44.5-222.5 A/m 2 (1-5 A) at constant EG $20 \mathrm{~mm}$ and $\mathrm{pH}_{\mathrm{i}} 7$. The results as COD and color reduction are presented in Fig. 6a, b. Figure shows COD removal efficiencies of 52, $60,69,79$ and $74 \%$ and color removal efficiencies of 64 , $67,73.5,82$ and $78 \%$ at CD 44.4, 89, 178 and $222.5 \mathrm{~A} / \mathrm{m}^{2}$, respectively. The results ascertain increase in the removal efficiency with applied $\mathrm{CD}$. The rate of anodic dissolution of aluminum increases at higher CDs, resulting in a greater amount of coagulant and precipitant production. Consequently, this resulted in a higher removal efficiency of organics. Apart from this, increase in smaller-sized bubbles at high CD results in a higher removal efficiency of organics via $\mathrm{H}_{2}$ flotation, in addition to the effect of coagulation (Song et al. 2008). The excess formation of aluminum and its hydroxide cations at $\mathrm{CD}=222.5 \mathrm{~A} / \mathrm{m}^{2}$ 
(a)

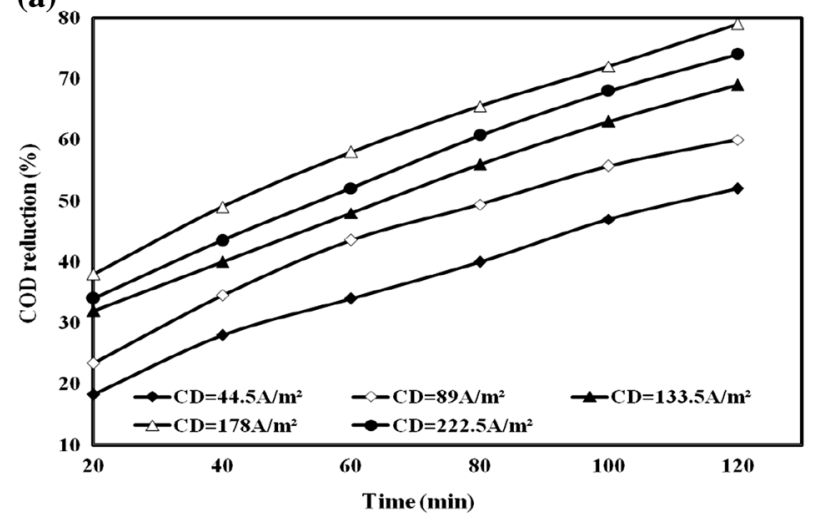

(b)

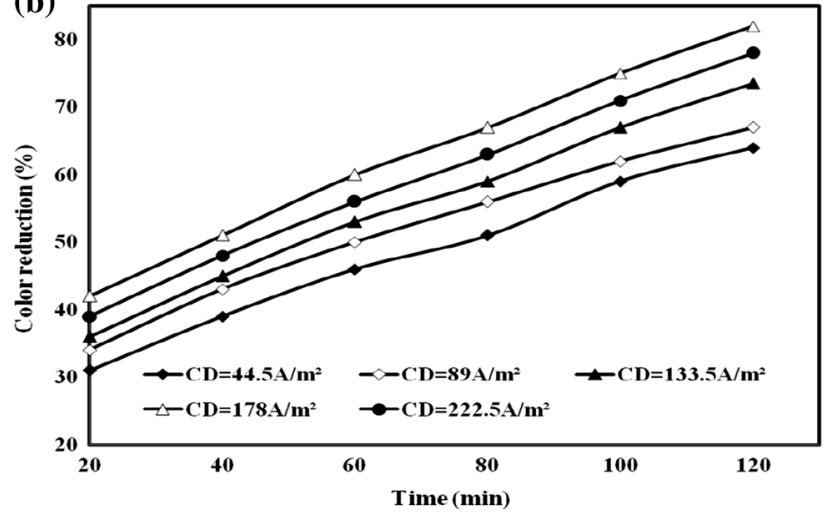

Fig. 6 Effect of $\mathrm{CD}$ on a COD removal and b color removal. $\mathrm{pH}_{\mathrm{i}} 7$, EG $20 \mathrm{~mm}$

results in colloid restabilization, which causes less COD reduction $(74 \%)$ as compare to $79 \% \mathrm{COD}$ reduction at $178 \mathrm{~A} / \mathrm{m}^{2}$.

\section{Effect of current density on $\mathrm{pH}$ changes}

Since $\mathrm{pH}$ is one of the influencing parameters in EC treatment, therefore, its variation with change in $\mathrm{CD}$ at $\mathrm{pH}_{\mathrm{i}}$ 7 and EG $20 \mathrm{~mm}$ was also observed, which is shown in Fig. 7a. The $\mathrm{pH}_{\mathrm{i}} 6$ was found to reach $\mathrm{pH} 7.7,7.8,7.95$, 8.05 and 8.15, respectively, at CD 44.5, 89, 133.5, 178 and $222.5 \mathrm{~A} / \mathrm{m}^{2}$ in $t_{\mathrm{R}} 120 \mathrm{~min}$. This may be due to formation of negative ions (anion) at high CD.

\section{Effect of current density on temperature change}

Change in $\mathrm{CD}$ also affects other parameters including temperature. Therefore, change in temperature at different CD with treatment time $\left(t_{\mathrm{R}}\right)$ was also noted for ECT at EG $20 \mathrm{~mm}$ and $\mathrm{pH}$ 7. The results are presented in Fig. 7b. It was found that temperature reached to $65,68,71,74$ and $76{ }^{\circ} \mathrm{C}$ from room temperature $27{ }^{\circ} \mathrm{C}$ when EC process was performed at $\mathrm{CD} 44.5,89,133.5,178$ and $222.5 \mathrm{~A} / \mathrm{m}^{2}$ for $t_{\mathrm{R}}=120 \mathrm{~min}$, respectively. Temperature affects floc
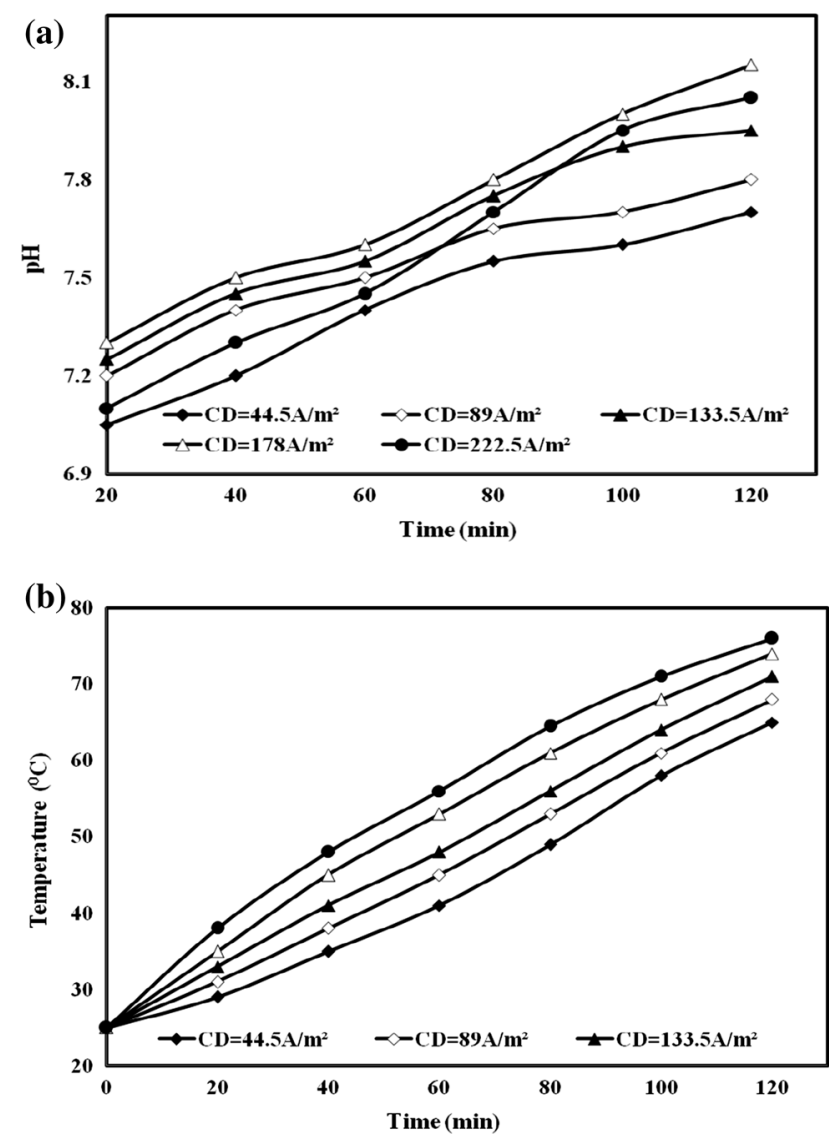

Fig. 7 Effect of $\mathrm{CD}$ on a pH changes and b temperature changes. $\mathrm{pH}_{\mathrm{i}}$ 7, EG $20 \mathrm{~mm}$

formation, reaction rates and conductivity. It has been reported that current efficiency of aluminum initially increases with increase in temperature up to $60{ }^{\circ} \mathrm{C}$. Further increase in temperature results in decrease in current efficiency. When the temperature is too high, there is shrinkage of large pores of the $\mathrm{Al}(\mathrm{OH})_{3}$ gel, which cause the formation of dense flocs that are more likely to deposit on the electrode surface (Chen 2004). Increasing temperature also enhances the solubility of aluminum. However, it seems that increasing temperature can have positive and negative effects on the removal efficiency. It is possible that the effect of temperature on removal efficiency depends on the removal mechanism of pollutants.

Kinetics study

COD reduction data generated from ECT were used to evaluate kinetics data. In EC process, when current is applied to the electrode, $\mathrm{Al}^{3+}$ cations form and it comes in the wastewater. These $\mathrm{Al}^{3+}$ cations further change into aluminum hydroxide cations. Cations neutralize the colloidal particles of wastewater which have negative charge. The neutralized mass settles down and it further removes 
organics which come on its way by sweep coagulation. The $\mathrm{H}_{2}$ formed on cathode also removes organics of wastewater by its floatation. Thus, removal of organics of SIWW takes place by forming solid residues by various mechanisms. The supernatant is obtained at the top and solid residue settles down. The organic removal process can be expressed as:

SIWW (organics) $\stackrel{\text { Metalcations+MetalHydraxides }}{\longrightarrow}$ Soluble organics

(supernatant) $\uparrow+$ Solid residues $\downarrow$

SIWW contains various organics which can be lumped as COD. The Eq. 13 can be written as

$\mathrm{COD} \stackrel{\text { Metalcations }+ \text { MetalHydraxides }}{\longrightarrow}$ Soluble organics

$\uparrow+$ Solid residues $\downarrow$

In the ECT process, CD plays a major role. With increases in $\mathrm{CD}$ up to certain limit, $\mathrm{COD}$ reduction also increases. Thereafter, COD removal decreases. Similarly, COD reduction rate decreases with time, and after a certain electrolysis time, the COD removal becomes almost constant. Therefore, the rate equation, i.e., COD removal rate can be represented by a global power law equation:

$\frac{-d(\mathrm{COD})}{\mathrm{d} t}=k^{n} \mathrm{COD}^{n} \mathrm{CD}^{\mathrm{m}}$

For constant CD, Eq. (15) can be reduced to

$\frac{-d \mathrm{COD}}{\mathrm{d} t}=k \mathrm{COD}^{\mathrm{n}}$

where

$k=k^{n} C D^{m}$

Equation 16 was solved numerically using Euler's integration method and fitted well for second order with respect to COD. The experimental values are shown by point and numerical calculated values by line (Fig. 8). The values of $k$ were evaluated as $2.20 \times 10^{-6}, 3.0 \times 10^{-6}$, $3.70 \times 10^{-6}, \quad 5.25 \times 10^{-6}$ and $4.30 \times 10^{-6} \mathrm{dm}^{3} /$ (mg min) at $\mathrm{CD} 44.5,89,133.5,178$ and $202.5 \mathrm{~A} / \mathrm{m}^{2}$, respectively. Order with respect to $\mathrm{CD}$ in range $44.5-178 \mathrm{~A} / \mathrm{m}^{2}$ is evaluated to be 0.591 . Guven et al. (2009) reported 1.2 orders with respect to COD for ECT of simulated beet sugar factory wastewater. They have not reported order with respect to $\mathrm{CD}$.

Liquid-solid separation

\section{Settling}

Settling is one of the economical processes used to separate solid and liquid of slurry or suspension. In settling study, whole process can be generally divided into five regimes: (1) clear, (2) discrete, (3) flocculent, (4) hindered and (5) compressed regimes. Using the batch sedimentation data, a continuous thickener may be designed (Font 1990; Font et al. 1999; Richardson et al. 2003). Thus, batch sedimentation tests are immensely important. Figure 9 presents solid-liquid interface in the form of dimensionless height $\left(H / H_{\mathrm{i}}\right)$ as a function of settling time at different system $\mathrm{pH}_{\mathrm{i}}$. Initially, a steady state decrease in the solid/ liquid interface was seen, which is called regime of zone settling. Thereafter, transition settling occurred. In the third stage, steady state compression settling took place. Overall, in the present study, the settling rate was found in the order of $\mathrm{pH} 10>\mathrm{pH} 2>\mathrm{pH} 8>\mathrm{pH} 7>\mathrm{pH} 4$. Results indicate settling at basic and acidic conditions are better as compared to at neutral $\mathrm{pH}$.

\section{Filterability}

Filtration is another unit operation used to separate solids contained in slurry. In the EC process, small colloidal particles form, which agglomerate and form as large-sized particles. For filtration of such agglomerate, the particle filtration method is one of the options. Filtration of such a slurry can be done in industrial scale by using either a plate and frame filter or a rotary vacuum filter. Gravity filtration can also be used for generating experimental data. Equation (18) proposed by MaCabe et al. (2001) can be used for the constant pressure filtration using a filter paper on a Büchner funnel.

$\frac{\Delta t}{\Delta V}=\frac{\mu \alpha C}{A^{2} \Delta P} \cdot V+\frac{\mu}{A \Delta P} \cdot R_{\mathrm{m}}$

where $\Delta t$ is the time interval of filtration, $\Delta V$ is the filtrate volume collected up to that time interval, $C$ is the solids concentration in the slurry, $V$ is the total liquid filtrate volume collected up to the time interval $t, \mu$ is the viscosity of the liquid filtrate, $\Delta P$ is the pressure drop across the filter $=\rho g h, A$ is the filtration area, $R_{\mathrm{m}}$ is the resistance of the filter medium, and $\alpha$ is the specific resistance to filtration.

After recording the experimental data volume of the filtrate as a function of time, a plot of $\Delta t / \Delta V$ versus $V$ gives a straight line, which is shown in Fig. 10. The values of $R_{\mathrm{m}}$ and $\alpha$ were evaluated from the slope and the intercept of plot and are presented in Table 3. The values of $\alpha$ were found to be 7.8, 3.0, 1.9, 2.1, 2.2 and $3.7 \times 10^{13}$ at $\mathrm{pH} 2,4$, $6,7,8$ and 10, respectively. The data show that filterability at $\mathrm{pH} 6$ is the best which is followed by that at $\mathrm{pH} 7$. The value of $R_{\mathrm{m}}$ has importance at initial stage of filtration only, which is the highest at $\mathrm{pH} 2$ and the lowest at $\mathrm{pH} 7$. Specific cake resistance values have been reported by Barnes et al. (1981). These values are $4-12 \times 10^{13} \mathrm{~m} / \mathrm{kg}$ 

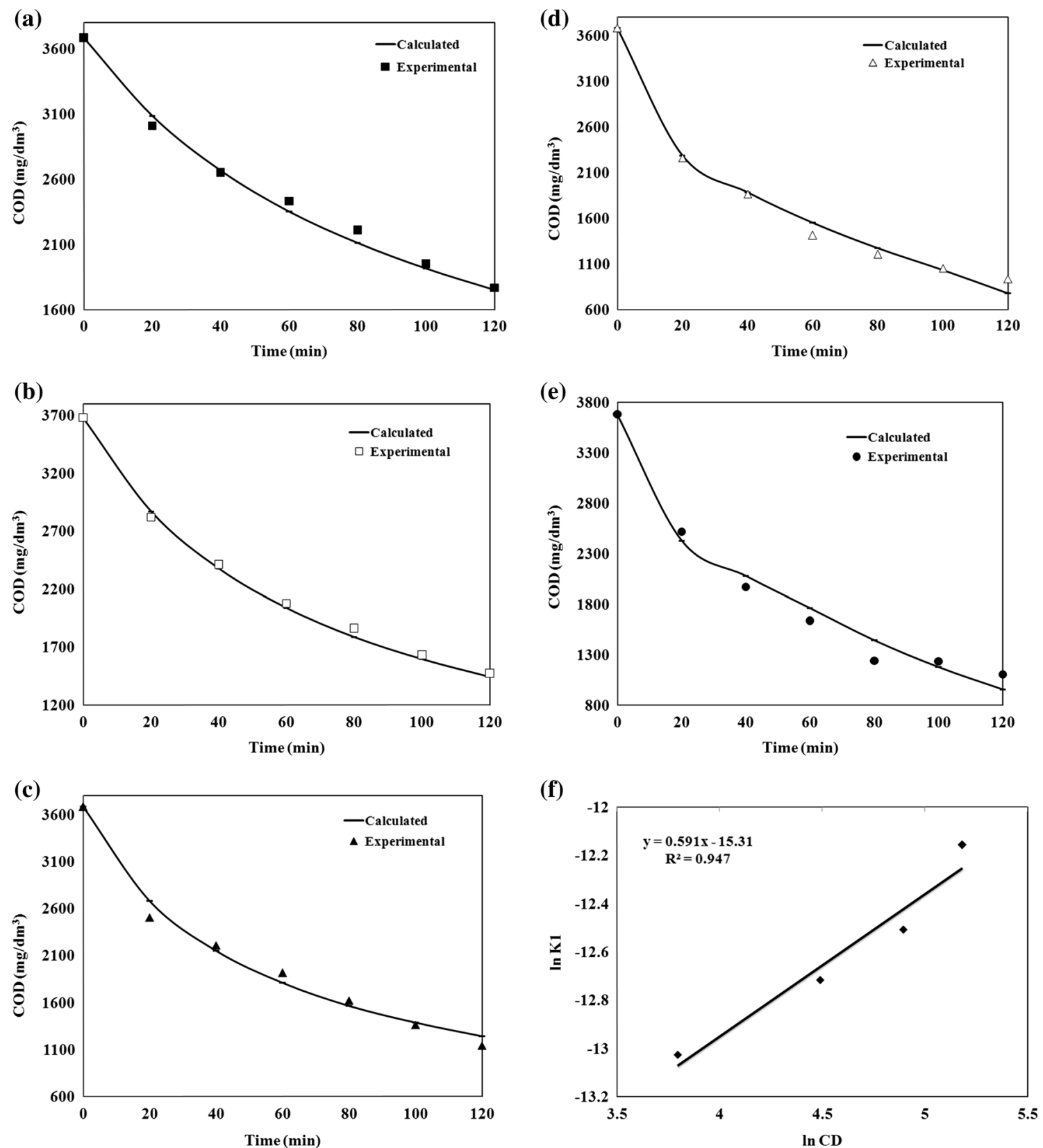

Fig. 8 Kinetics plot for EC treatment. COD reduction at a $44.5 \mathrm{~A} / \mathrm{m}^{2}, \mathbf{b} 99 \mathrm{~A} / \mathrm{m}^{2}, \mathbf{c} 143.5 \mathrm{~A} / \mathrm{m}^{2}, \mathbf{d ~} 198 \mathrm{~A} / \mathrm{m}^{2}$, e $242.5 \mathrm{~A} / \mathrm{m}^{2}$ and f plot for $\ln k_{1}$ and current density

for activated sludge and $3-30 \mathrm{~m} / \mathrm{kg}$ for digested sludge. Our values are in the range of $2-8 \times \mathrm{m} / \mathrm{kg} 10^{13}$. The filtration studies have also been presented by other investigators for treatment of pulp and paper mill effluent (Mahesh et al. 2006) and distillery effluent (Chaudhari et al. 2007).

\section{Analysis of filtrate and residues}

The properties of filtrate and residues are presented in Tables 1, 4, respectively. From Table 1, it can be seen that large amount of COD $\left(3,682-699 \mathrm{mg} / \mathrm{dm}^{3}\right)$ was reduced after the EC process. COD is responsible for organic load in the effluent. Color also reduced from dark brown to pale yellow. Color is responsible to hinder the oxygen diffusion and sunlight penetration and thus, obstruct the photosynthesis process. Protein, chloride, phosphate, hardness and total solids also reduced to satisfactory level. The treated effluent still contains $699 \mathrm{mg} / \mathrm{dm}^{3}$ COD which does not meet the discharge effluent standard, but it can be good feed for further treatment by membrane separation process to reach zero discharge. In our laboratory, the EC-treated 
SIWW was further treated by coagulation. By this, COD value reduced to $200 \mathrm{mg} / \mathrm{dm}^{3}$ and color practically nil.

Solid residues obtained on filter paper was dried at $110{ }^{\circ} \mathrm{C}$ and analyzed for various parameters. The properties are presented in Table 4 . The highest mass of residues was obtained at $\mathrm{pH} 6\left(5.83 \mathrm{~kg} / \mathrm{m}^{3}\right)$ and the lowest at $\mathrm{pH} 2$

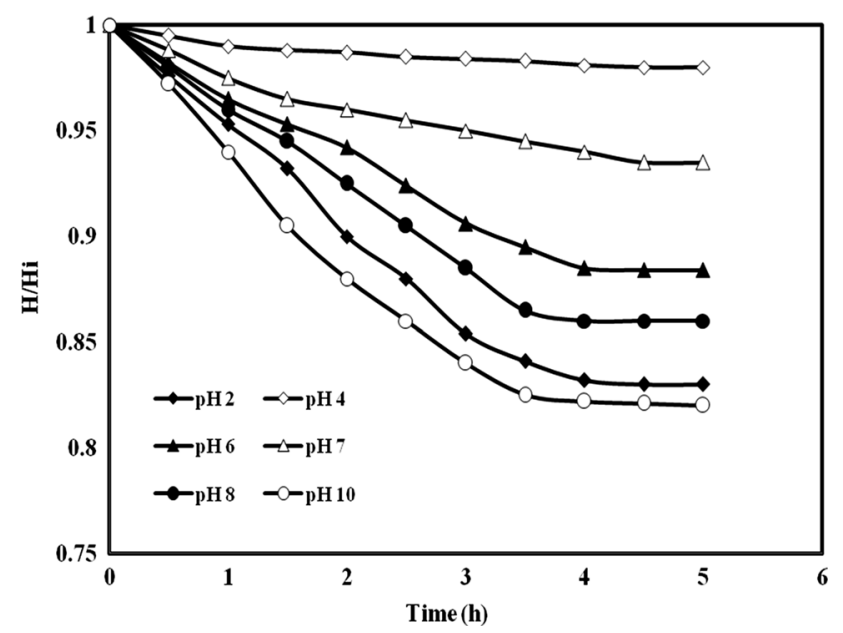

Fig. 9 Settling characteristics of treated SIWW. EG $20 \mathrm{~mm}, \mathrm{CD}$ $89 \mathrm{~A} / \mathrm{m}^{2}$

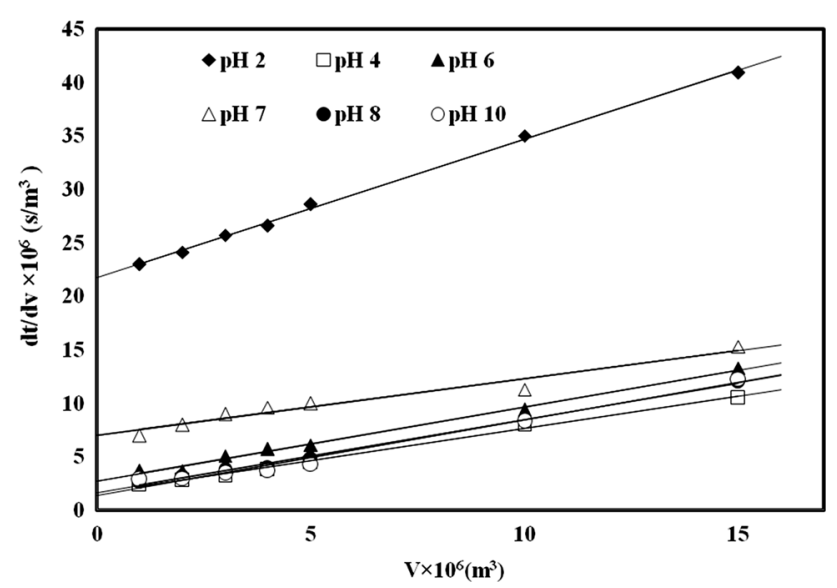

Fig. 10 Filterability of the electro coagulated slurry at different $\mathrm{pH}$. EG $20 \mathrm{~mm}, \mathrm{CD} 89 \mathrm{~A} / \mathrm{m}^{2}$ $\left(2.46 \mathrm{~kg} / \mathrm{m}^{3}\right)$. The residues were flaky, hard, and difficult to grind and had different color. EC-treated organic residues possessing good heating values have already been reported (Mahesh et al. 2006).

\section{Cost analysis of EC Treatment of SIWW}

Electricity and electrodes are considered to be the two major cost-involving components when applying ECT to wastewaters. The cost of energy for SIWW treatment and the cost of aluminum electrode material consumed were obtained from the experimental results and the sum was taken as the operating cost. To treat SIWW at $\mathrm{pH}=7$ and $\mathrm{CD}=178 \mathrm{~A} / \mathrm{m}^{2}$, energy consumption was $58 \mathrm{Wh} / \mathrm{dm}^{3}$ and electrode loss was $0.82 \mathrm{~g} / \mathrm{dm}^{3}$.

i. Cost of energy

Power consumption per $\mathrm{m}^{3}$ of SIWW treated $=58 \mathrm{kWh}$

At an energy price in the Indian market $=$ INR 4/ $\mathrm{kWh}$

Cost of energy per $\mathrm{m}^{3}$ SIWW treated $=$ INR 232

ii. Cost of aluminum

Aluminum required per $\mathrm{m}^{3}$ of $\mathrm{SIWW}=820 \mathrm{~g}$ Cost of $3 \mathrm{~mm}$ aluminum sheet on bulk purchase $=$ INR $210 / \mathrm{kg}$

Cost of aluminum per $\mathrm{m}^{3}$ of SIWW treated $=0.82 \mathrm{~kg} \times \mathrm{INR} 210 / \mathrm{kg}=\mathrm{INR} 172 / \mathrm{m}^{3}$

Operating $\operatorname{cost}=$ Cost of energy + Cost of electrode $=232+172=$ INR $404(\mathrm{USD}=6.22)$ per $\mathrm{m}^{3}$ of SIWW treated.

\section{Conclusion}

The EC process with aluminum electrode proved to be an effective method for treatment of SIWW. The COD reductions of $32,42,45,60,52$ and $42 \%$ and color reductions of 43, 54, 57, 67, 64 and $49 \%$ were obtained at constant $\mathrm{CD} 89 \mathrm{~A} / \mathrm{m}^{2}$ and $\mathrm{pH} 2,4,6,7,8$ and 10 ,

Table 3 Filterability of the treated SIWW. CD 89 A/m², EG $20 \mathrm{~mm}$

\begin{tabular}{|c|c|c|c|c|c|c|}
\hline S. no & Initial $\mathrm{pH}$ & $\begin{array}{l}\mathrm{Kp} \times 10^{-12} \\
\mathrm{~s} / \mathrm{m}^{6}\end{array}$ & $\begin{array}{l}\beta \times 10^{-6} \\
\mathrm{~s} / \mathrm{m}^{3}\end{array}$ & $\begin{array}{l}C \\
\mathrm{~kg} / \mathrm{m}^{3}\end{array}$ & $\begin{array}{l}\alpha \times 10^{-13} \\
\mathrm{~m} / \mathrm{kg}\end{array}$ & $R_{\mathrm{m}} \times 10^{-11}$ \\
\hline 1 & 2 & 2.0 & 21.73 & 2.46 & 7.8 & 7.78 \\
\hline 2 & 4 & 0.706 & 1.05 & 3.46 & 3.0 & 0.37 \\
\hline 3 & 6 & 0.5 & 2.28 & 5.83 & 1.9 & 0.81 \\
\hline 4 & 7 & 0.45 & 7.33 & 4.87 & 2.1 & 0.26 \\
\hline 5 & 8 & 0.37 & 2.62 & 3.12 & 2.2 & 0.93 \\
\hline 6 & 10 & 0.63 & 1.41 & 2.96 & 3.7 & 0.53 \\
\hline
\end{tabular}


Table 4 Analysis of residue obtained after EC (Al plate) at different $\mathrm{pH}, \mathrm{CD} 89 \mathrm{~A} / \mathrm{m}^{2}$

\begin{tabular}{|c|c|c|c|c|c|c|c|}
\hline S. no & Parameter/pH & 2 & 4 & 6 & 7 & 8 & 10 \\
\hline 1 & $\begin{array}{l}\text { Weight of residue } \\
\left(\mathrm{kg} / \mathrm{m}^{3}\right)\end{array}$ & 2.46 & 3.46 & 5.83 & 4.87 & 3.12 & 2.96 \\
\hline 2 & Color & Light gray & Light gray & Gray & Gray & Gray & Dark gray \\
\hline 3 & Nature & $\begin{array}{l}\text { Flakey and easy } \\
\text { to grind }\end{array}$ & $\begin{array}{l}\text { Flakey and } \\
\text { tough to grind }\end{array}$ & $\begin{array}{l}\text { Flakey and } \\
\text { tough to grind }\end{array}$ & $\begin{array}{l}\text { Flakey and } \\
\text { tough to grind }\end{array}$ & $\begin{array}{l}\text { Flakey and } \\
\text { tough to grind }\end{array}$ & $\begin{array}{l}\text { Flakey and } \\
\text { tough to grind }\end{array}$ \\
\hline 4 & Size $(\mathrm{mm})$ & $1-4$ & $2-6$ & $2-6$ & $1-5$ & $1-5$ & $1-6$ \\
\hline 6 & $\begin{array}{l}\text { Percentage } \\
\text { convertible COD }\end{array}$ & 38 & 42 & 60 & 52 & 45 & 35 \\
\hline
\end{tabular}

respectively. COD and color reduction were found to increase with increase in CD. COD reductions of 52, 60, 69, 79 and 74 and color reductions of 64, 67, 73.5, 78 and 82 were obtained at $\mathrm{pH} 7$ and $\mathrm{CD} 44.5,89,133.5,178$ and $222.5 \mathrm{~A} / \mathrm{m}^{2}$, respectively. Energy consumption increased with $\mathrm{pH}$ and was $16.2,17.14,20,22.85,32$ and $33.7 \mathrm{Wh}$, respectively, for treatment of $1 \mathrm{dm}^{3}$ effluent at $\mathrm{pH} 2,4,6$, 7,8 and 10. At this $\mathrm{pH}$, electrode losses were $0.55,0.60$, $0.51,0.63,0.68$ and $0.62 \mathrm{gm}$ per $\mathrm{dm}^{3}$ SIWW treatment. Kinetics studies evaluated COD reduction rate to be of second order with respect to organics material (COD) and 0.591 order with respect to $\mathrm{CD}$. Overall, $\mathrm{pH}=7$, $\mathrm{EG}=20 \mathrm{~mm}$ and $\mathrm{CD}=178 \mathrm{~A} / \mathrm{m}^{2}$ were the optimum operating conditions that resulted in COD reduction of $79 \%$ and color reduction of $78 \%$. Energy consumption and electrode loss was also less at $\mathrm{pH} 7$ as compared to treatment at other $\mathrm{pH}$. Filterability of treated effluent was the best at $\mathrm{pH}$ 6. Further treatment of electrochemically treated SIWW by coagulation reduced COD of SIWW to $<200 \mathrm{mg} / \mathrm{dm}^{3}$ and color to practically nil.

\section{List of symbols}

\begin{tabular}{|c|c|}
\hline$A$ & Filtration area $\left(\mathrm{m}^{2}\right)$ \\
\hline$C$ & Solid concentration in the slurry $\left(\mathrm{kg} / \mathrm{m}^{3}\right)$ \\
\hline $\mathrm{CD}$ & Current density $\left(\mathrm{A} / \mathrm{m}^{2}\right)$ \\
\hline COD & Chemical oxygen demand \\
\hline EG & Electrode gap \\
\hline$F$ & Faraday's constant, 96,500 C/mol \\
\hline$I$ & Current $(\mathrm{A})$ \\
\hline$k$ & Reaction rate constant $\left[\mathrm{dm}^{3} /(\mathrm{mg} \min )\right]$ \\
\hline$M$ & $\begin{array}{l}\text { Amount of substances dissolved ( } g \text { of } \\
\mathrm{M} / \mathrm{cm}^{3} \text { ) }\end{array}$ \\
\hline SEC & $\begin{array}{l}\text { Specific energy consumption }[\mathrm{kWh} / \\
\left.\left(\mathrm{dm}^{3} \mathrm{~kg} \text { COD removal }\right)\right]\end{array}$ \\
\hline$t$ & Time $(s, \min , \mathrm{h})$ \\
\hline$V$ & Voltage across the electrodes \\
\hline$V$ & $\begin{array}{l}\text { Total liquid filtrate volume collected up to } \\
\text { the time interval } t\left(\mathrm{~m}^{3}\right)\end{array}$ \\
\hline$\Delta P$ & Pressure drop across the filter $=\rho g h(\mathrm{~Pa})$ \\
\hline
\end{tabular}

$\Delta t$

$\Delta V$

$\alpha$

$\mu$

$R_{\mathrm{m}}$
Time interval of filtration (s)

Filtrate volume collected up to that time interval $\left(\mathrm{m}^{3}\right)$

Specific resistance to filtration, also called as SCR

Viscosity of the liquid filtrate (Pa s)

Resistance of the filter medium $\left(\mathrm{m}^{-1}\right)$

\section{References}

Ahlawat R, Srivastava VC, Mall ID, Sinha S (2008) Investigation of the electrochemical treatment of cotton blue dye solutions using aluminium electrodes. Clean 36:863-869

Akanksha Roopashree G, Lokesh KS (2013) Comparative Study of electrode material (iron, aluminium and stainless steel) for treatment of textile industry wastewater. Int $\mathrm{J}$ Environ Sci 4(4):519-531

Aoudj S, Khelifa A, Nadjib N, Mouna M, Hamitouche H (2010) Electrocoagulation process applied to wastewater containing dyes from textile industry. Chem Eng Prog 49(11):1176-1182

Asaithambi P, Matheswaran M (2011) Electrochemical treatment of simulated sugar industrial effluent: optimisation and modeling using a response surface methodology. Arab J Chem. doi:10. 2016/jarabic.2011.10.004

Asaithambi P, Saravanathamizhan R, Matheswaran M (2014) Comparison of treatment and energy efficiency of advanced oxidation processes for the distillery wastewater. Int $\mathbf{J}$ Environ Sci Technol. doi:10.1007/s13762-014-0589-9

Barnes D, Bliss PJ, Gould BW, Vallentine BW (1981) Water wastewater engineering systems. Pitman Publishing Inc., New York

Bayramoglu M, Kobya M, Can OT, Sozbir M (2004) Operating cost analysis of electrocoagulation of textile dye wastewater. Sep Purif Technol 37:117-125

Bayramoglu M, Eyvaz M, Kobya M (2007) Treatment of the textile wastewater by electrocoagulation: economical evaluation. Chem Engg J 128:155-161

Brillas E, Sauleda R, Casado J (1998) Degradation of 4-chlorophenol by anodic oxidation, electro-Fenton, photoelectro-Fenton and peroxi-coagulation processes. J Electrochem Soc 145:759-765

Can OT, Kobya M, Demirbas E, Bayramoglu M (2006) Treatment of the textile wastewater by combined electrocoagulation. Chemosphere 62:181-187

Cartier S, Theoleyre MA, Decloux M (1997) Treatment of sugar decolorizing resin regeneration waste using nano filtration. Desalination 113:7-17 
Chaudhari PK, Mishra IM, Chand S (2007) Decolourization and removal of chemical oxygen demand (COD) with energy recovery: treatment of biodigester effluent of a molasses-based alcohol distillery using inorganic coagulants. Colloids Surf A 296:238-247

Chen G (2004) Electrochemical technologies in wastewater treatment. Sep Purif Technol 38:11-41

Clesceri L, Greenberg AE, Trussell RR (eds) (1989) Standard methods for water and wastewater examination, 17th edn. APHA, New York

Drogui P, Asselia M, Brar SK, Benmoussa H, Blais JF (2008) Electrochemical removal of pollutants from agro-industry wastewaters. Sep Purif Technol 61:301-310

Environmental Health and Safety Guidelines for Sugar Manufacturing (2007) World Bank group environmental health and safety guidelines. The World Bank Group Washington, DC

Esplugas S, Gimenez J, Contreras S, Pascual E, Rodriguez M (2002) Comparison of different advanced oxidation processes for phenol degradation. Water Res 36:1034-1042

Faust SD, Aly OM (1987) Adsorption process for water treatment. Butterworth's Publishers, Stoneham

Font R (1990) Calculation of the compression zone height in continuous thickeners. AIChE 36:3-12

Font R, Garcia P, Rodriguez M (1999) Sedimentation test of metal hydroxides: hydrodynamics and influence of $\mathrm{pH}$. Colloids Surf A 157:73-84

Guimarac C, Porto P, Olivera R, Mota M (2005) Continuous decolorisation of sugar refinery wastewater in a modified biological contractor with Phanerochate chrysosporium immobilized on polyurethane foam disk. Proess Biotech 40:535-540

Guven G, Perendeci A, Tanyolac A (2009) Electrochemical treatment of simulated beet sugar factory wastewater. Chem Engg J 151:149-159

Holt PK, Barton GW, Mitchell CA (2005) The future for electrocoagulation as a localised water treatment technology. Chemosphere 59:355-367

Kamaraj R, Ganesan P, Vasudevan S (2013) Removal of lead from aqueous solutions by electrocoagulation: isotherm, kinetics and thermodynamic studies. Int J Environ Sci Technol. doi:10.1007/ s13762-013-0457-z

Kim TM, Park C, Shin EB, Kim S (2002) Decolorization of disperses and reactive dyes by continuous electrocoagulation process. Desalination 150:165-175

Kushwaha JP (2013) A review on sugar industry wastewater: sources, treatment technologies, and reuse. Desalin Water Treat. doi:10. 1080/19443994.2013.838526

Kushwaha JP, Srivastava VC, Mall ID (2011) Studies on electrochemical treatment of dairy wastewater using aluminum electrode. AIChE J 57:2589-2598

LaPara TM, Konopka A, Nakatsu CH, Alleman JE (2000) Thermophilic aerobic wastewater treatment in continuous-flow bioreactors. J Environ Eng 126:739-744

MaCabe WL, Smith JC, Harriot P (2001) Unit operations of chemical engineering, 6th edn. McGraw-Hill, New York

Mahesh S, Prasad B, Mall ID, Mishra IM (2006) Electrochemical degradation of pulp and paper mill wastewater. Part 2. Characterization and analysis of sludge. Ind Eng Chem Res 45(16):5766-5774
Maleki HMG, Almassi M, Hejazi MA, Minaei S (2014) Harvesting of microalgae by electro-coagulation-flocculation for biodiesel production: an investigation of the effect of operational parameters and forecast model using response surface methodology. J Biosci 4(7):258-269

Ndjomgoue-Yossa AC, Nanseu-Njiki CP, Kengne IM, Ngameni E (2014) Effect of electrode material and supporting electrolyte on the treatment of water containing Escherichia coli by electrocoagulation. Int J Environ Sci Technol. doi:10.1007/s13762-0140609-9

Nordsom DK, May HM (1989) Aqueous equilibrium data for mononuclear aluminium species. In: Sposito G (ed) The environmental chemistry of aluminium. CRC Press, Boca Raton, pp 29-55

Ponselvan FIA, Kumar M, Malviya JR, Srivastava VC, Mall ID (2009) Electrocoagulation studies on treatment of biodigester effluent using aluminum electrodes. Water Air Soil Poll 199:371-379

Richardson JF, Harker JH, Backhurst JR (2003) Coulson and Richardson's Chemical engineering, particle technology and separation processes, vol 2, 5th edn. Elsevier, A Division of Reed Elsevier India Pvt. Ltd., Chennai

Serge T, Nanseu-Njiki CP, Ngameni E, Hadjiev D, Darchen A (2010) Treatment of dairy effluents by electrocoagulation using aluminum electrodes. Sci Total Environ 408:947-952

Singh S, Srivastava VC, Mall ID (2013a) Mechanism of dye degradation during electrochemical treatment. J Phy Chem C 117:15229-15240

Singh S, Srivastava VC, Mall ID (2013b) Mechanistic study of electrochemical treatment of basic green 4 dye with aluminum electrodes through zeta potential, TOC, COD and color measurement, and characterization of residues. RSC Adv 3:16426-16439

Singh S, Srivastava VC, Mall ID (2013c) Multistep optimization and residue disposal study for electrochemical treatment of textile wastewater using aluminum electrode. Int $\mathbf{J}$ Chem React Eng $11: 1-16$

Song S, Yao J, He Z, Qiu J, Chen J (2008) Effect of operational parameters on the decolorization of C.I. reactive Blue 19 in aqueous solution by ozone-enhanced electrocoagulation. J Hazard Mater 152:204-210

Sridhar R, Sivakumar V, Maran JP, Thirugnanasambandham K (2014) Influence of operating parameters on treatment of egg processing effluent by electrocoagulation process. Int $\mathbf{J}$ Environ Sci Technol. doi:10.1007/s13762-013-0301-5

Szpyrkowicz L, Naumczyk J, Zilio-Grandi F (1995) Electrochemical treatment of tannery wastewater using $\mathrm{Ti} / \mathrm{Pt}$ and $\mathrm{Ti} / \mathrm{Pt} / \mathrm{Ir}$ electrodes. Water Res 29:517-524

Tan BH, Teng TT, Omar AKM (2000) Removal of dyes and industrial dye wastes by magnesium chloride. Water Res 34:597-601

Vik EA, Dale AC, Arild SE, Egil TG (1984) Electrocoagulation of potable water. Water Res 18:1355-1360

Vogal AI (1958) A text book of quantitative inorganic analysis, 3rd edn. Longman, London 